\title{
The Right to Silence: Inferences and Interference
}

\section{Introduction}

In August 2012, the government of New South Wales (NSW) announced plans to bring forward legislation which would curtail the right to silence of a suspect in a criminal case, while under police questioning, by allowing for an adverse inference to be drawn from such silence at subsequent trial (O'Farrell 2012). The Evidence Amendment (Evidence of Silence) Act 2013, which gives effect to this proposal, provides for the insertion of s 89A into the Evidence Act 1995 in the following terms: '(1) In a criminal proceeding for a serious indictable offence, such unfavourable inferences may be drawn as appear proper from evidence that, during official questioning in relation to the offence, the defendant failed or refused to mention a fact:

(a) that the defendant could reasonably have been expected to mention in the circumstances existing at the time, and

(b) that is relied on in his or her defence in that proceeding.'

This Act was passed by the Parliament of NSW and assented to on 25 March 2013, though it is yet to be proclaimed. Its content goes against the recommendations of the NSW Law Reform Commission, contained in their 2000 report (NSW Law Reform Commission 2000:2.138), and, outside of the government and the police, it seems that most significant participants in the criminal process were opposed to the introduction of s 89A. ${ }^{1}$ While reference was made in a number of submissions on the original Bill

\footnotetext{
*BCL, PhD: Lecturer in Law, Socio-Legal Research Centre, School of Law and Government, Dublin City University, Glasnevin, Dublin 9, Ireland: yvonne.daly@dcu.ie
} 
(the Evidence Amendment (Evidence of Silence) Bill 2012) and in the Law Reform Commission report, to similar provisions introduced in England and Wales and in Singapore, there has been little reference to restrictions on the right to silence in the Republic of Ireland (hereinafter referred to as Ireland). ${ }^{2}$ Ireland, an oft-forgotten (or, perhaps, ignored) common law jurisdiction, is a good comparator to NSW on this issue, not least because of the absence in both jurisdictions of duty solicitor schemes for the provision of legal advice to suspects. Knowledge of the experience of interferences with the pre-trial right to silence in Ireland might be beneficial to lawmakers and other interested parties, not only in NSW but in any jurisdiction considering interference with the right to silence. In New Zealand, for example, the right to silence ${ }^{3}$ has recently been compromised under the examination order provisions of the Search and Surveillance Act 2012.

This article outlines the manner in which restrictions on the pre-trial right to silence came to have a place in Irish law, making comparative comment on the newly-created s 89A in NSW. The article highlights the initial introduction of an inference-drawing provision similar to that now in existence under s 89A and the subsequent acceptance of inference-drawing provisions of a more expansive nature in later years. Along with the Irish experience, reference is made throughout to issues arising under s 34 of the Criminal Justice and Public Order Act 1994 in England and Wales, and relevant

\footnotetext{
${ }^{1}$ The NSW Bar Association suggested that 'The government should abandon this proposal, for which no relevant stakeholders (apart from the police) advocate' (NSW Bar Association 2012:16).

2 Three sentences of the NSW Law Reform Commission report referenced the Irish position, as it stood in 2000 (NSW Law Reform Commission 2000:2.29). Besides the fact that this is an extremely brief explication of the situation in Ireland, significant changes in the Irish regime have occurred since then. Notably, Dr Jeremy Gans' submission on the Evidence Amendment (Evidence of Silence) Bill 2012 does make reference to some elements of the Irish situation (Gans 2012).

${ }^{3}$ Protected under ss 23(4) and 25(d) of the New Zealand Bill of Rights Act 1990. See also s 32 of the Evidence Act 2006 in that jurisdiction.
} 
decisions of the European Court of Human Rights, particularly in the context of the interaction between the right to silence and the right to legal advice.

\section{The right to silence: A fundamental right}

The right to silence, often interchangeably or alternatively referred to as the 'privilege against self-incrimination', ${ }^{4}$ may be thought to include a number of different protections, or immunities, ${ }^{5}$ but in basic terms, in the context of criminal proceedings, it is the entitlement of a suspect to refuse to answer questions put to him/her or to provide any information to the prosecution (McGrath 2005:11.04). It applies both at trial, where it operates as a right to refuse to take the stand and give evidence, and pre-trial, whereby a suspect cannot be compelled to speak against his/her own interest under official questioning by the police. ${ }^{6}$

Over a number of centuries, the right to silence became well-established in most common law jurisdictions $^{7}$ and it is also now specifically set out within a number of international agreements (e.g. International Covenant on Civil and Political Rights 1966:Art 14; Statute of the International Tribunal for Rwanda, 1994:Art 20; Statute of the International Tribunal for the Former Yugoslavia 1993:Art 21; Rome Statute of the International Criminal Court 1998:Art 55; European Convention on Human Rights and Fundamental Freedoms 1950:Art 6). The historic underpinnings of the right have been rehearsed in many quarters and there is little value in an expansive reproduction

\footnotetext{
${ }^{4}$ Zuckerman suggests that the 'privilege against self-incrimination' is a misnomer as the accused must be presumed innocent until proven otherwise, therefore he suggests that the term 'right to silence' may in fact be more accurate (Zuckerman 1989:305). This article will primarily employ the term 'right to silence'.

${ }^{5}$ See the judgment of Lord Mustill in R. v Director of the Serious Fraud Office, ex p. Smith.

${ }^{6}$ The trial-based right to silence, effectively the right not to testify, was established first. A pre-trial equivalent was later recognised in order to protect the trial-based right (McGrath 2005:11.70). See also $R v$ Director of Serious Fraud Office, ex parte Smith (at 32).

${ }^{7}$ For example, England and Wales, Ireland, Canada, the United States, Australia and New Zealand.
} 
of same here. Suffice it to say that while differences of opinion on the exact impetus for the protection of the right and the exact timing of its emergence on the criminal justice scene may abound, ${ }^{8}$ it is a long-seated, well-established right.

Various rationales have been put forward for the right, both at the trial and pre-trial stages: personal autonomy and the dignity of the individual, including the right to privacy (Dennis 1995; Wilson $\mathrm{J}$ in Thomson Newspapers Ltd. $v$ Canada (Director of Investigation and Research, Restrictive Trade Practices Commission)) and the protection of the individual from cruel choices (Goldberg $\mathrm{J}$ in Murphy $v$ Waterfront Commission of New York Harbor; Walsh and Martens JJ in Saunders v United Kingdom); the presumption of innocence (O'Connor and Cooney 1980:236); the prevention of police abuse of power (Zuckerman 1989:318; Dennis 1995:350/351); and, the right to freedom of expression (Heaney and McGuinness $v$ Ireland). It is perhaps a combination of all of these which truly accounts for the existence and ongoing protection of the right to silence. However, there is a divergence of views on this right. Some see it as an important protection for the suspect in the criminal process, while others view it as a hindrance to the investigative efforts of police and to the ultimate goal of the criminal process, i.e. the prosecution and repression of crime (Cross 1970-71; Criminal Law Revision Committee 1972; Zuckerman 1989; Working Group on the Right to Silence 1989; McConville et al 1991; Royal Commission on Criminal Justice 1993; Zuckerman 1994; Dennis 1995; Leo 1996; Mirfield 1997;

\footnotetext{
${ }^{8}$ Some commentators have traced the roots of the right to silence to the 13th century when the English ecclesiastical courts began to administer the 'oath ex officio' in their search for heretics and a later public revulsion to the practice: per Walsh $\mathrm{J}$ in Saunders $v$ United Kingdom. Others have suggested that its origins are to be found later, in an aversion to the practices of the ecclesiastical and prerogative courts of the 17th century: the 'High Commission' and the 'Star Chamber' (Wigmore 1940; Herman 1992; Easton 1998). More have contended that while the phraseology of the right to silence/privilege against self-incrimination was employed earlier, it was not until the mid-18th century that it truly became a substantive part of the common law under the influence of defence counsel and the progression of the adversarial model of criminal procedure which brought about its ultimate acceptance (Langbein 1994).
} 
Easton 1998). This dichotomy of views was clear in the discussion on the introduction of inference-drawing provisions in NSW. The government and the police argued for greater investigative powers while most other stakeholders argued for the preservation of this fundamental, procedural protection.

While Ireland is a good comparator jurisdiction for NSW on this issue, one significant difference between the jurisdictions in relation to the protection of the right to silence must be acknowledged at the outset: the right is protected at common law in Australia, with additional legislative prohibition of inferences from pre-trial silence provided under s 89 of the Evidence Act 1995; however, the right has constitutional status under Bunreacht na hÉireann, the Constitution of Ireland 1937. This difference is not as pronounced as might initially seem to be the case as the protection afforded to the right in NSW, and indeed throughout Australia generally, has been of a very high level ${ }^{9}$ and, by comparison, the elevated status of the right in Ireland has failed to prevent its significant curtailment. ${ }^{10}$

\section{Ireland: First into the fray}

Ireland was not the first common law jurisdiction to introduce inference-drawing provisions, but it may have been the first to interfere with the right to silence in

\footnotetext{
${ }^{9}$ See, for example, Hammond $v$ The Commonwealth where Brennan J described the right to silence as 'a freedom so treasured by tradition and so central to the judicial administration of criminal justice' (at 3 ) and the more recent case of $R v$ Seller and McCarthy where Garling J noted the 'regard which is paid to the privilege against self-incrimination in the United States of America' and, while acknowledging the constitutional protection afforded to the privilege in the latter jurisdiction, further stated that 'the source of the privilege, and the reasons for its continued existence are similar in both Australia, as a part of the common law, and in the US as a part of the Constitution' (at 153).

${ }^{10}$ Although no explicit reference to the right to silence is made in the text of the Irish Constitution, the Supreme Court has declared its constitutional status. See Heaney and McGuinness v Ireland and the discussion in the text below.
} 
modern times. ${ }^{11}$ And rather than tread gently upon a well-established right of this nature, the Irish legislature trampled upon it with gusto.

The Irish criminal process bears the scars of the so-called 'Troubles' in Northern Ireland. The conflict in that jurisdiction has spilled over into the Republic of Ireland on a number of occasions and the fear of an escalation in violence relating to the 'Troubles' along with a desire to control those planning criminality either north or south of the border has led to the introduction of draconian measures over the years. More often than not, measures initially enacted as extraordinary powers relating to paramilitary activity have become normalised and have, in time, extended to the ordinary corpus of the criminal law (Walsh 1989; Hillyard 1993; Daly 2009). This is true, to a large extent, of incursions on the right to silence.

In December 1938 and January 1939 the Irish Republican Army (the IRA) proclaimed that its Executive Council was the legitimate and legal government of every part of Ireland and it purported to declare war on the United Kingdom. The Offences Against the State Act 1939 was introduced as a response to this and a significant part of its armoury was the provision of new pre-trial, investigatory powers which had never before been recognised under Irish law. Among those was s 52 which provided that a

\footnotetext{
${ }^{11}$ In Singapore, inferences from silence have been allowed since 1977 under the Criminal Procedure Code (Spore) ss 122(6) and 123(1), as inserted by the Criminal Procedure (Amendment) Act 1976 (Spore); in Northern Ireland, inference-drawing provisions were first enacted in 1988 under the Criminal Evidence (Northern Ireland) Order 1988; and in England and Wales, inferences from silence have been allowed since 1994 under the Criminal Justice and Public Order Act 1994. The first modern Irish incursion on the right to silence came within the Offences Against the State Act 1939. In fact, if one looks back further, the legislature of the Irish Free State, under the Constitution (Amendment No.17) Act 1931, made it a criminal offence, potentially punishable by death, for an arrested person to refuse to answer particular questions put to him/her by police officers acting under certain prescribed powers. However, the Constitution of the Irish Free State was replaced by the current Irish Constitution in 1937 and the right to silence was held to have regained its traditionally protected position under the common law: Re National Irish Bank (under investigation) (No.1) per Barrington J.
} 
person arrested and detained under the Act could be required by a garda ${ }^{12}$ to account for his/her movements and actions during a specified period and to give all the information which s/he possessed in regard to the commission or intended commission by another person of a specific offence. Failure or refusal to give the required account or information, or the provision of false or misleading information was an offence punishable by a term of imprisonment not exceeding six months.

An offence based on pre-trial silence is, of course, a different concept to the inference-drawing provision which has been introduced in NSW. ${ }^{13}$ It is a more obvious barrier to the exercise of the right to remain silent because it has a more concrete consequence, i.e. imprisonment.

The operation of s 52 was challenged before both the Irish courts and the European Court of Human Rights (the European Court) in Heaney and McGuinness v Ireland. Its constitutionality was upheld domestically, but, at a European level, it was held to breach Art 6 of the European Convention on Human Rights; the right to a fair trial.

In Ireland, the courts expressed differing views on the constitutional locus of the right to silence. It is not an expressed right in the text of the Constitution and while the High Court viewed it as an important element of the right to a fair trial (Art 38.1), the Supreme Court located it as a corollary of the right to freedom of expression (Art 40.6). Relying on the proviso to the freedom of expression provision, to the effect that

\footnotetext{
${ }^{12}$ A member of the Irish police service, an Garda Síochána (translates as the "guardians of the peace"). An individual police officer is referred to as a 'garda'. The plural is 'gardaí'.

${ }^{13}$ The Search and Surveillance Act 2012 in New Zealand, by comparison, creates an offence of noncompliance with an examination order, punishable by up to one year's imprisonment, or a fine of up to $\$ 40,000$ for a body corporate: s 173 . One saving grace of the New Zealand law, as compared to s 52 in Ireland, is that there is judicial oversight through the initial authorisation of an examination order where certain conditions are fulfilled: s 38 .
} 
this right may be curtailed where the exigencies of public order or morality so require, the Supreme Court held that the State was entitled to restrain the citizen's right to silence in pursuit of the legitimate aim of maintaining public peace and order, although the right must be affected as little as possible. The incursion on the right to silence contained in s 52 was held to be proportionate to the State's aim of protecting itself and preventing the public from disorder.

Finding a breach of the right to a fair trial, however, the European Court held that s 52 involved an unacceptable interference with the right to silence as the degree of compulsion placed on suspects to provide information under the provision in effect 'destroyed the very essence of their privilege against self-incrimination and their right to remain silent' (at 55).

The first European Court case to recognise the right to silence/privilege against selfincrimination was Funke v France, which centred on the production of documents. In that case, it was held that, although not specifically set out in the text of the ECHR, the right to silence/privilege against self-incrimination is protected as part of the right to a fair trial under Art 6 ECHR. Later, in Murray v United Kingdom, the European Court stated that that the right to silence and the right not to incriminate oneself are generally recognised international standards which lie at the heart of the notion of a fair procedure under Art 6 (at 45). While the facts of Heaney led the Court to find a breach of that article, it has on other occasions clarified that the right to silence is not 
an absolute right and it may legitimately be curtailed in certain circumstances. ${ }^{14}$ This is discussed further below in the context of inference-drawing provisions.

The Irish Supreme Court upheld the constitutionality of s 52 and its inherent interference with the exercise of the right to silence. However, it later undermined the practical benefits of provisions of that nature in the context of prosecutions by holding that the admissibility of any statement obtained from a suspect on pain of penal sanction was governed by the Art 38.1 fair trial requirements and the central test applied in relation to such admissibility was voluntariness (Re National Irish Bank (under investigation) (No.1); Dunnes Stores v Ryan). While admissibility is to be decided on a case-by-case basis, in reality compelled statements will rarely pass a test of voluntariness and will therefore generally be excluded from evidence at trial. While arguably the gardaí might still wish to pressurise a suspect to provide information under the threat of the commission of an offence under s 52 even though such a compelled confession might not be admissible at trial, the value of offences based on pre-trial silence for the purposes of securing convictions was ultimately undermined by the Irish Supreme Court and little use of s 52, or provisions like it, is now made. However, the 1939 Act, the Irish Supreme Court's stance on the constitutional location of the right to silence and the application of a proportionality test to interference with same at both a domestic and European level cleared the way for future further incursions on that right.

\section{Inference-drawing}

\footnotetext{
${ }^{14}$ In Murray, the European Court held that the right to silence is not absolute and it may be allowable under the ECHR for the right to be interfered with by way of inference-drawing provisions in appropriate circumstances (at 66).
} 
Inference-drawing provisions are designed to encourage suspects to answer police questions in the investigative stage. There are several statutory provisions in Ireland which aim to encourage this by providing for inferences to be drawn at trial from a failure or refusal to mention certain matters or answer certain questions in the pre-trial process. However, Irish legislation gives no indication of the types of inferences that might be drawn from the pre-trial silence of the accused, and neither does s 89A in NSW. An English Judicial Studies Board Specimen Direction lists the inferences which may be drawn under s 34 of the Criminal Justice and Public Order Act 1994 in England and Wales, where the accused seeks to rely on a fact at trial which s/he did not mention in the pre-trial period, which, in the circumstances existing at the time s/he 'could reasonably have been expected to mention'. This may give an indication of the future application of s 89A in relation to serious indictable offences. Under the Specimen Direction, possible inferences include that:

- The fact now relied on is true but the defendant, for reasons of his own, chose not to reveal it;

- The fact now relied on is irrelevant;

- The 'fact' now relied on is of more recent invention;

- The defendant's present answer to the prosecution case is fabricated;

- The defendant is guilty (Crown Court Bench Book 2010:261).

The Irish courts have not addressed the specifics of the likely inferences to be drawn, nor has the legislature provided any guidance in this regard. Despite this vagueness, the legislature has established quite an inference arsenal in recent years. Since the prosecutorial value of offences based on silence has been undermined by precedent of both the European Court of Human Rights and the Irish Supreme Court (as outlined 
above), inferences have taken over the mantle of curtailing pre-trial silence. Initially inferences could only be drawn in relation to a failure or refusal to account for marks, substances or objects, or presence in a particular place, where evidence of the matter was given in later proceedings. However, this initially restrained approach has given way over the years to far broader incursions on the right to silence.

The first inference-drawing provisions were promulgated in the Criminal Justice Act 1984 and sought to induce answers to quite specific questions, raised on the basis of existing evidence. Section 18 allowed for an adverse inference to be drawn at trial against an accused person, who, following arrest, failed or refused to account, on being requested to do so by a garda, for the presence of any object, substance or mark on his/her person, clothing or footwear, or in his/her possession, or in the place where s/he was arrested. Section 19 allowed for an inference to be drawn from failure or refusal to account for presence at a particular place, in similar circumstances. ${ }^{15}$ These provisions, which were and still are applicable to all arrestable offences, ${ }^{16}$ clearly interfere with the right to silence, by attaching consequences to its exercise. However, as compared with s 52 of the 1939 Act before them, and with the broader provisions which later followed, the level of intrusion occasioned on the right is diluted to some extent by the specifics of their construction. This, along with safeguards legislatively attached to the provisions, and a number of other protections, meant that they were

\footnotetext{
${ }^{15}$ The garda who requests the relevant information must hold a reasonable belief that the presence of the object, substance or mark, or the suspect's presence at a particular place, may be attributable to the suspect's participation in the commission of the offence for which s/he has been arrested. Provisions similar to ss 18 and 19 had previously been introduced in Northern Ireland under the ss 5 and 6 of the Criminal Evidence (Northern Ireland) Order 1988.

${ }^{16}$ Any offence which is potentially punishable by at least five years imprisonment: Criminal Law Act 1997, section 2 (1), as amended by the Criminal Justice Act 2006, s 8.
} 
accepted as a proportionate interference with the constitutionally protected right to silence in Rock $v$ Ireland. ${ }^{17}$

In time, however, inference-drawing provisions which were broader in their operation were introduced, though they were initially confined to offences of a specific nature. In 1996, a provision, applicable only to drug-trafficking offences, was introduced whereby an inference could be drawn against an accused at trial for failure to mention, during the pre-trial process, a fact which s/he later relied on in his/her defence which s/he ought reasonably to have mentioned at the time of questioning or charging (Criminal Justice (Drug Trafficking) Act 1996 s 7). In 1998, an identical provision was promulgated which applied in the case of offences against the state (Offences Against the State (Amendment) Act 1998 s 5). These provisions mirrored s 34 of the Criminal Justice and Public Order Act 1994 in England and Wales.

In 2007, the legislative decision was made to allow inferences to be drawn from pretrial silence in relation to all serious offences, and so the 1996 and 1998 provisions were repealed and replaced by s 19A of the Criminal Justice Act 1984, as inserted by the Criminal Justice Act 2007. Section 19A provides that an inference may be drawn from the pre-trial failure of the accused to 'mention any fact relied on in his $[/$ her $]$...

\footnotetext{
${ }^{17}$ As in Heaney, the Supreme Court stated that the pre-trial right to silence is protected as a corollary of the right to freedom of expression but it may be restricted in order to serve the exigencies of public order and morality. It was held that ss 18 and 19 were proportionate as they represented the necessary balance between the right to silence and the duty of the State to defend and protect the life, person and property of all its citizens. The court also held that two important limiting factors were in operation to combat any perceived imbalance. First, the inferences which might be drawn were evidential in nature only and could not be the sole basis for any conviction. Secondly, in deciding what inferences may be drawn, the court is obliged to act in accordance with the principles of constitutional justice and, having regard to an accused's right to a fair trial, is under a constitutional obligation to ensure that no improper or unfair inferences are drawn from the relevant silence (at 501).
} 
defence...being a fact which in the circumstances existing at the time clearly called for an explanation'. ${ }^{18}$

Certain pre-requisites and safeguards (which also apply to ss 18 and 19) are set out in the legislation creating s 19A:

- a person shall not be convicted solely or mainly on an inference drawn, ${ }^{19}$ although, any inference drawn may amount to corroboration of any evidence in relation to which the failure is material;

- inferences can only be drawn where the accused has been told in ordinary language that it may harm the credibility of his/her defence if s/he does not mention something which s/he later relies on in court;

- no inference ought to be drawn unless the accused was afforded a reasonable opportunity to consult a solicitor before his/her failure to account for the relevant matters or to mention the relevant fact;

- the court or jury in deciding whether or not to draw inferences ought to consider when the account or fact concerned was first mentioned by the accused; and

- no inference shall be drawn in relation to a question asked in an interview unless either the interview has been electronically recorded or the detained person has consented in writing to the non-recording of the interview.

Despite the existence of these safeguards, s 19A severely impedes the pre-trial exercise of the right to silence by placing pressure on persons suspected of

\footnotetext{
${ }^{18}$ For a discussion of the slightly quirky phrasing of s 19A see Daly 2007.

${ }^{19}$ The current NSW proposal suggests that an inference cannot be drawn if it is the only evidence of guilt (s 89A(3)). Besides this cumbersome wording, this does not prohibit conviction mainly on the basis of such an inference.
} 
involvement in any arrestable offence to provide details of all matters to questioning gardaí so as to ensure that a jury at trial will not be invited to consider pre-trial silence as symptomatic of guilt.

The formulation of s 19A requires that an inference can only be drawn from the failure to mention a particular fact when (i) such a fact 'clearly called for an explanation' during the pre-trial period, and (ii) it was a fact which the suspect sought to rely upon at trial. Sections 18 and 19 as originally formulated required that 'evidence of the said matters', i.e. the account not originally given, was given at trial, but this was removed under the 2007 Act and the current requirement is only that the relevant fact 'clearly called for' an explanation at the pre-trial stage of questioning. The double threshold requirement of $\mathrm{s} 19 \mathrm{~A}$ then is more stringent than the reformulated ss 18 and 19. This double threshold is also a component of s $89 \mathrm{~A}$ in NSW. A far lower threshold exists in relation to the most recent weapon in the Irish legislature's inference-drawing arsenal though: s 72A of the Criminal Justice Act 2006, as inserted by the Criminal Justice (Amendment) Act 2009.

Section $72 \mathrm{~A}$ applies to the rather broadly-drawn concept of participating in or contributing to any activity of a 'criminal organisation' ${ }^{20}$ In such cases, an inference may be drawn at trial from the pre-trial failure of a suspect to 'answer a question material to the investigation of the offence'. The safeguards applicable to ss 18,19

\footnotetext{
${ }^{20}$ A 'criminal organisation' is defined under s 70 of the Criminal Justice Act 2006 as amended by s 3 of the Criminal Justice (Amendment) Act 2009 as 'a structured group, however organised, that has as its main purpose or activity the commission or facilitation of a serious offence'. A 'structured group' is defined as 'a group of 3 or more persons, which is not randomly formed for the immediate commission of a single offence, and the involvement in which by 2 or more of those persons is with a view to their acting in concert; for the avoidance of doubt, a structured group may exist notwithstanding the absence of all or any of the following: (a) formal rules or formal membership, or any formal roles for those involved in the group; (b) any hierarchical or leadership structure; (c) continuity of involvement by persons in the group.'
} 
and 19A are replicated in relation to $\mathrm{s} 72 \mathrm{~A}$. A question is not to be regarded as being material to the investigation of the offence unless the garda concerned reasonably believed that the question related to the participation of the defendant in the commission of the offence.

'Any question material to the investigation of the offence' includes, inter alia,

- a request that the suspect give a full account of his/her movements, actions, activities or associations during any specified period relevant to the offence being investigated;

- questions related to statements or conduct of the suspect implying or leading to a reasonable inference that $\mathrm{s} / \mathrm{he}$ was at a material time directing the activities of a criminal organisation;

- and, questions relating to any benefit that the suspect may have obtained from directing a criminal organisation or committing a serious offence within a criminal organisation.

Unlike the double threshold requirement of s 19A or even the 'clearly called for' prerequisite of ss 18 and 19 , under s $72 \mathrm{~A}$ an inference against the accused may be drawn ostensibly on the grounds that s/he refused to co-operate with the investigation into his/her guilt. It seems that an inference may be drawn whether or not an answer to the particular question was 'clearly called for' or the failure to provide such an answer is a specifically relevant matter in the context of the later trial. Failure alone gives rise to the inference. 
Section $72 \mathrm{~A}$, more than ever before, moves the focus of the criminal case from the courtroom and the legal defence of the charge to the garda station and the initial investigation of the offence and it places a heavy onus on the suspect within the pretrial process to provide the gardaí with information on which to base their further investigations. While it may be confined to the context of 'organised crime', s $72 \mathrm{~A}$ is symptomatic of the ongoing shift backwards from the public courtroom to the private police interrogation room. Protections for suspects in the police station have not kept pace with the erosion of the traditionally-protected right to silence and the apparent shift in the centre of gravity of the criminal process. ${ }^{21}$

This is not only an Irish phenomenon, but is a feature of many modern criminal justice systems. In the context of the right to silence, John Jackson (2009) has noted the sidelining of the courts in favour of the police station. He suggests that states are 'increasingly 'front-loading' the forensic enterprise [of fact-finding] into the pre-trial phase in order to expedite proceedings' (Jackson 2009:851). He further suggests that there is no reason why this should not be done, so long as, importantly, there are suitable safeguards in place. If the police station is becoming more like a courtroom on the prosecution side, then courtroom-like protections should exist on the defence side also. Jackson recommends that

'[a]t the point when there is a basis in evidence for putting allegations against a suspect, he or she ought arguably to be given the same or equivalent defence rights as are available at trial which include, most importantly, access to legal advice, disclosure of the evidence against him and an authenticated record of any interview either by audio or video tape. But such safeguards cannot be

\footnotetext{
${ }^{21}$ Packer considered that the centre of gravity of 'crime control' model (as opposed to his 'due process' model) would have its centre of gravity in the early, non-adjudicative pre-trial stage of the criminal process (Packer 1968:162).
} 
effective unless they are accompanied by a Miranda-style rule prohibiting any questioning until they are put in place and because ... suspects are inevitably put under pressure when faced with criminal allegations, especially when they are in custodial interrogation, suspects in custody should not be able to waive these rights, at least not until they have had an opportunity to speak to a lawyer' (Jackson 2009:851; Miranda v Arizona).

He goes on to argue that the right to silence should be given a special weighting at the pre-trial stage so that a suspect is afforded procedural and effective defence rights from the earliest stages of the criminal process (Jackson 2009:852-853). This would be based on a recognition of the vulnerable position of suspects in the pre-trial interrogational stage of the criminal process and the potential risk of false confessions. Jackson suggests that when a certain level of evidence exists against the suspect he may then be invited to respond to the allegations made against him (Jackson 2009:853-854). He could, as at trial, admit to these allegations, answer questions, refuse to answer questions and submit to judicial inquiry, or offer a written explanation of his conduct.

This is not the position provided for under any of the provisions on the statutebook in Ireland, or the newly-introduced s 89A in NSW. While certain safeguards may be provided, they are not of the extent suggested by Jackson and, as explained below, in both the Irish and NSW situations even the right to legal advice is not as strong a protection as it might seem at first glance. 
Legal advice and the right to silence: The view from the European Court of Human Rights

A defence to a criminal charge is a legal construct and the question of what fact or facts should be mentioned in pre-trial questioning in order to later make out a specific defence is a difficult one for a suspect. Defences such as self-defence, provocation, duress and insanity, for example, have legal meanings which may not be readily apparent to the layman. Access to legal advice for suspects whose pre-trial failure to mention a particular fact might later be the basis for adverse inference is therefore of utmost importance.

The link between the right to silence and the right to legal advice has been specifically made by the European Court of Human Rights. In Murray v United Kingdom, a breach of Art 6 ECHR was found, not on the grounds of inferences being drawn from pre-trial silence per se, but because the suspect against whom the inference-drawing legislation was invoked was denied access to legal advice in the initial stages of his detention. The Court held that the right to silence is not absolute and it upheld the inference-drawing provisions of the Criminal Evidence (Northern Ireland) Order 1988. The Court stated that the decision as to whether or not the drawing of adverse inferences from a suspect's pre-trial silence was in violation of his/her rights under Art 6 should be determined in light of all the circumstances of a given case, having particular regard to the situations where inferences may be drawn, the weight to be attached to them by the national courts in their assessment of the evidence and the degree of compulsion inherent in the situation (at 47). The Court stated that

'National laws may attach consequences to the attitude of an accused at the initial stages of police interrogation which are decisive for the prospects of the 
defence in any subsequent criminal proceedings. In such circumstances Article $6 \ldots$ will normally require that the accused be allowed to benefit from the assistance of a lawyer already at the initial stages of police interrogation' (at 63).

In the context of the inference-drawing provisions of the Northern Ireland Order, the Court held that 'it is of paramount importance for the rights of the defence that an accused has access to a lawyer at the initial stages of police interrogation' (at 66). Furthermore, the Court declared that

' $[\mathrm{t}] \mathrm{o}$ deny access to a lawyer for the first 48 hours of police questioning, in a situation where the rights of the defence may well be irretrievably prejudiced, is - whatever the justification for such denial - incompatible with the rights of the accused under Article 6' (at 66).

This is a clear statement from the European Court of Human Rights on the importance of legal advice to ensure fairness to a suspect who is faced with the possibility that his silence under police questioning may have adverse consequences for him at trial.

The European Court has had to consider the practical implications of the connection between the right to legal advice and the right to silence, through a series of cases centring on the operation of s 34 of the Criminal Justice and Public Order Act 1994 in England and Wales. The essential pragmatic question was whether an inference can be drawn on the basis of a suspect's failure to mention a particular fact in the pre-trial process where such failure was based on the advice of his/her legal adviser to remain silent. On the one hand, if the suspect is entitled to legal advice, surely s/he must be 
entitled to rely on that advice. However, the inference-drawing provisions would be entirely defeated if every suspect could avoid their application by saying that $\mathrm{s} / \mathrm{he}$ only failed to mention a particular fact because his/her solicitor advised him/her to remain silent. The domestic courts in England and Wales grappled with this for a time and the issue eventually came before the European Court of Human Rights.

In Condron v U.K., the European Court found a breach of the right to a fair trial where a judicial direction had left the jury at liberty to draw an adverse inference notwithstanding that its members may have been satisfied that the defendant's assertion that he remained silent only because he had been legally advised to do so was plausible. ${ }^{22}$ A number of cases followed in the English courts, however, which seemed to suggest that it was not enough to avoid an inference for the suspect to have simply relied upon the legal advice received; s/he must also have done so reasonably. In $R v$ Howell, for example, the Court of Appeal stated that it did not consider that once it is shown that the legal advice given has been genuinely relied upon, adverse inference is thereby disallowed. On the facts therein, the Court held that there was no soundly based objective reason for silence and the jury was entitled to draw inferences from the appellant's 'no comment' interview. In $R v$ Hoare and Pierce, Auld L.J. stated that

'[t]he question in the end, which is for the jury, is whether regardless of advice, genuinely given and genuinely accepted, an accused has remained silent not because of that advice but because he had no or no satisfactory explanation to give' (at 1821).

\footnotetext{
${ }^{22}$ This was followed by the English Court of Appeal in $R v$ Betts and Hall.
} 
This ties both genuineness and reasonableness together, though reasonableness remains the most important concern.

In Beckles $v$ U.K., the failure of the trial judge to direct the jury, under s 34 , to consider the genuineness of the accused's reasons for remaining silent led the European Court to find a breach of Art 6. The case was then returned to the Court of Appeal where Woolf C.J. stated:

'...in a case where a solicitor's advice is relied upon by the defendant, the ultimate question for the jury remains under section 34 whether the facts relied on at the trial were facts which the defendant could reasonably have been expected to mention at interview. If they were not, that is the end of the matter. If the jury consider that the defendant genuinely relied on the advice, that is not necessarily the end of the matter. It may still not have been reasonable for him to rely on the advice, or the advice may not have been the true explanation for his silence' ( $R v$ Beckles at 2844).

It seems then that reliance on legal advice to remain silent must be both genuine and reasonable in order to avoid the drawing of any inference allowable under statute in England and Wales. ${ }^{23}$

\section{Legal advice and the right to silence: Irish experience and NSW provisions}

Legislative compliance with the ECHR and the case-law of the European Court has become increasingly important in Ireland in light of the incorporation of the ECHR into domestic law by the European Convention on Human Rights Act 2003. This may

\footnotetext{
${ }^{23}$ This is reflected in the Judicial Studies Board Specimen Direction for s 34 cases whereby a jury must consider both the genuineness of the accused's reliance on legal advice and the reasonableness of such reliance (Crown Court Bench Book 2010:258-267).
} 
explain, in large part, the 2007 addition to all inference-drawing provisions, of the proviso that no inference is to be drawn unless the accused was afforded a 'reasonable opportunity' to obtain legal advice prior to the occasion on which the relevant silence occurred. In 2011 a further safeguard was added, though it is yet to be commenced, such that if a suspect who has been arrested and detained requests access to legal advice, he is not to be questioned until he has had an opportunity to consult with a solicitor. ${ }^{24}$ This, again, was precipitated by events at a European level. While the link between the right to silence and the right to legal advice was made in the European Court of Human Rights over fifteen years ago (Murray v United Kingdom), the Court clarified in 2008, in Salduz v Turkey that the right of access to legal advice is an essential pre-condition to any form of custodial questioning, including but not limited to the context of inference-drawing procedures. Furthermore, the United Kingdom Supreme Court applied the Salduz ruling in Cadder v Her Majesty's Advocate and found that Scottish law, which did not require pre-trial legal advice for a detained suspect prior to interrogation, was incompatible with the ECHR. It seemed, accordingly, that the Irish position at the time, with no prohibition on questioning a suspect prior to the arrival of his requested solicitor, was at variance with the Strasbourg jurisprudence (Heffernan 2011).

\footnotetext{
${ }^{24}$ Criminal Justice Act 1984 s 5A as inserted by the Criminal Justice Act 2011 s 9 . The period of time spent waiting for consultation with the solicitor is excluded in reckoning the statutorily permitted period of detention. This period should generally not to exceed 3 hours, or such other shorter period as may prescribed by ministerial regulations, though in the case of a person detained in a Garda station between midnight and 8 a.m. the period should not to exceed 6 hours, or such other shorter period as may prescribed by ministerial regulations: s $5 \mathrm{~A}(2)$. Under s $5 \mathrm{~A}(3)$ a detained person will be taken to have waived his/her right to consult a solicitor if s/he refuses to consult with one who has made himself/herself available for that purpose. Questioning may commence when a person waives, or is deemed to have waived, his/her right to consult a solicitor: $\mathrm{s} 5 \mathrm{~A}(4)$. The requirement to refrain from questioning a detained person until s/he has had an opportunity to consult with a solicitor can be set aside by the member in charge in specified circumstances: s 5A(5).
} 
While Irish legislation may, as soon as the new provision is commenced, be in line with the minimum standard requirements of the ECHR in relation to pre-trial legal advice, the Irish incarnation of that right remains weak in its construction and application. As in NSW, there are no duty solicitor schemes in Ireland. ${ }^{25}$ In the absence of duty solicitor schemes, not every suspect undergoing police questioning will gain access to legal advice. In Ireland, there is an administrative scheme to provide pre-trial legal advice to impecunious suspects. ${ }^{26}$ It is available only to those satisfying a means test, however, and there is no specific right for suspects to be told of its existence. Furthermore, there is no formal method of selecting a solicitor to advise a suspect who cannot name one himself/herself. Garda stations in Ireland do not possess lists of solicitors who are willing and likely to be available to attend at the garda station and provide legal advice for detained suspects. Some stations may have informal arrangements with certain firms or may simply provide a suspect with a phone book to select a solicitor, but this is wholly unsatisfactory. Without formal lists of appropriate solicitors in garda stations, there is a clear danger that gardaì may be tempted, as they were in O'Brien v D.P.P., to suggest and contact legal advisors knowing that they will be unavailable to attend, thereby making it possible to question the suspect after a certain time has elapsed. Beyond that danger, there is also a risk that, in the absence of a formal listing of suitable legal advisors, a suspect would be distrustful of a solicitor suggested to him/her by the police as s/he may suspect that the solicitor is favoured for some ulterior reason or is in some way colluding with the

\footnotetext{
25 The idea of establishing a duty solicitor scheme in Ireland has been debated on a number of occasions. Most recently, the Criminal Legal Aid Review Committee concluded that a Duty Solicitor Scheme ought not to be established as it would lead to a lack of continuity for clients (Committee to Recommend Certain Safeguards for Persons in Custody and for Members of an Garda Sìochána 1978:62; Tormey Committee 1977; Criminal Legal Aid Review Committee 2002:Chapter 3).

${ }^{26}$ The Garda Síochána Station Legal Advice Scheme is an administrative scheme only and is restrictive in its means test (being available only to persons who are in receipt of Social Welfare payments or earning less than $€ 20,316$ per annum).
} 
police. If that were the case, the accused's right of access to legal advice would effectively be undermined as s/he would be unlikely to trust the advice of the solicitor in question.

Under s 89A in NSW, there seems to be recognition of the interrelated nature of the rights to silence and legal advice. Inferences can only be drawn under this provision where the suspect was given a special caution by an investigating official prior to the relevant failure or refusal to mention a relevant fact, the caution was given in the presence of an Australian legal practitioner acting for the defendant, and the defendant was given an opportunity to consult in private with this legal practitioner about the "general nature and effect of special cautions" (s 89A(2)). ${ }^{27}$ A special caution is defined in $\mathrm{s} 89 \mathrm{~A}(9)$ as

"a caution given to a person that is to the effect that:

(a) that person does not have to say or do anything, but it may harm the person's defence if the person does not mention when questioned something the person later relies on in court, and

(b) anything the person does say or do may be used in evidence."

The apparent meaning of $\mathrm{s} 89 \mathrm{~A}(2)$ is that no inference can be drawn if a lawyer representing the suspect was not physically present during the administration of the special caution. ${ }^{28}$ Two questions present themselves in this regard (i) what about a

\footnotetext{
${ }^{27}$ Although specific reference is made to legal advice on the general nature and effect of special cautions, presumably the legal practitioner may also advise his client on the substance of any allegations or on his position generally. This is not at all clear from the wording of the provision though.

${ }^{28}$ In his address on the Second Reading of the relevant Bill on March 132013 the Attorney General for NSW, Greg Smith, stated that "the provisions will not prevent a vulnerable person from being provided with the assistance of a support person during any investigative procedure; nor will they apply to Indigenous people who have exercised their right to speak to the Aboriginal Legal Service over the telephone. However, it will apply to suspects who have their lawyer present at the police station." He
} 
suspect who cannot afford to retain a lawyer?; and, (ii) what about a suspect who simply chooses not to retain a lawyer?

The original draft legislation specifically provided that a defendant is taken not to have been allowed an opportunity to consult an Australian legal practitioner if the defendant's means, and the circumstances, preclude the defendant from obtaining legal advice' (s 89A(7) of the Evidence Amendment (Evidence of Silence) Bill 2012). Although not explicitly stated in the finalised version of the Act, this principle appears to still apply: if a defendant cannot afford legal advice the practical result is that no inference can later be drawn from his silence. While this seems to alleviate the government from any requirement to create a duty solicitor scheme, or even to administer a police station advice scheme like the Irish scheme (unsatisfactory and limited as that is), it creates a very strange anomaly such that if you want to avoid having inferences drawn from your pre-trial silence it may be better to be poor than rich. If you cannot afford legal advice, no inference can be drawn under the legislation. Given the socio-economic background of the majority of offenders in the criminal process, this seems to render s 89A impotent from the beginning.

However, it is not only the impecunious suspect who can circumvent the drawing of inferences under s 89A. It seems that simply choosing not to retain a lawyer during the pre-trial period of official questioning will render the inference-drawing provision similarly impotent and unworkable. While there are of course risks involved in not obtaining legal advice while facing police questioning, one could at least avoid the risks of inference-drawing by choosing not to do so. The Attorney General for NSW, must be physically present. They are not present if they are simply in contact by telephone or some other electronic means." (Smith 2013) 
Greg Smith, suggested at the Second Reading of the relevant Bill that through the provisions requiring legal advice before inferences can later be drawn the new law "targets the higher end of criminal activity where suspects are more likely to bring their lawyers along when they are questioned" (Smith 2013). If the Act really sought to target the "higher end of criminal activity" it could have specified offences viewed as being of that nature rather than applying, as it does, to all serious indictable offences. Suggesting that the provisions relating to legal advice are a methodology to confine the application of the inference-drawing power, rather than side-step the necessity to provide state-financed legal advice, appears disingenuous. In any event, the Attorney General went on to note that if a suspect were to attempt to frustrate the operation of s 89A by not retaining a lawyer, a further opportunity exists to "require accused persons...to provide information" by way of the Criminal Procedure Amendment (Mandatory Pre-Trial Defence Disclosure) Act 2013.

This Act was introduced as part of a joint package with the Evidence Amendment (Evidence of Silence) Act 2013. It mandates both prosecution and defence pre-trial disclosure and attaches adverse consequences, in the form of unfavourable inferences, to defective defence disclosure (s 146A). In Ireland, while certain defence disclosure requirements are in place (e.g. alibi defence, notice of intention to call expert witness, notice of intention to call evidence of mental condition etc) no inferences can be drawn from failure to comply with the requirements. The potential consequence of non-compliance is that the evidence becomes inadmissible, though it may be admitted at the discretion of the court (see for example the Criminal Justice Act 1984 s 20, as amended). In England and Wales, however, inferences can be drawn from defective defence disclosure under the Criminal Procedure and Investigations Act 1996 as 
amended. As envisioned for the NSW provisions, in England and Wales "no comment" interviews are often accompanied by defective defence disclosure and lead to the drawing of inferences on two grounds (e.g. $R v E s s a$ ). The consequent elevated level of influence of inference-drawing provisions on a criminal trial ought to be a cause for concern, hesitation and consideration. The opposite seems to have been the case in NSW, where both pieces of legislation were enacted with some haste: the relevant Bills were introduced on March $13^{\text {th }}$ and assented to on March $25^{\text {th }}$.

Returning to the operation of $89 \mathrm{~A}$, an issue which arises in the context of a detained suspect who does retain a lawyer is whether or not such lawyer ought to be present throughout the interrogation in which a relevant failure or refusal to mention a fact occurs. So long as the lawyer was present at the time of cautioning and there was an opportunity for the suspect to consult with him on the general nature and effect of the special caution, the inference can be drawn and there is no requirement for the ongoing presence of a lawyer. A distinction between the Irish right to pre-trial legal advice and that in operation in NSW is notable here. Although s 89A may not require the presence of a lawyer throughout interrogation, there is no prohibition on same. In Ireland, by contrast, a suspect is entitled to telephone or meet with his/her legal adviser during the period of his detention at a garda station, but, there is no recognised right to have the adviser present during interview. ${ }^{29}$ The Irish right to legal advice is one of 'reasonable access' only. Its parameters have not been fully explored, but in practice it seems that a suspect will be entitled to one hour of consultation with his/her legal adviser in every six hours of detention, or ten minutes per one hour of detention

\footnotetext{
${ }^{29}$ In the seminal case of People (D.P.P.) v Healy the Supreme Court expressly reserved judgment as to whether or not the right of 'reasonable access' to pre-trial legal advice encompassed a right to have one's solicitor present throughout Garda interrogation. Later courts have, rather bluntly, accepted that there is no such right (Lavery v Member-in-Charge, Carrickmacross Garda Station; Barry v Waldron).
} 
(White 2000:17-18). In the context of inference-drawing provisions this carries specific dangers. While the accused might be provided a 'reasonable opportunity' to consult with his/her solicitor in the early stages of his detention, if questioning takes a turn in a new, previously unforeseen direction and the solicitor is not present to advise, the suspect is left without the benefit of relevant legal advice. It seems advisable for a suspect subject to the operation of s 89A in NSW who has retained a lawyer to opt to have him present throughout interrogation. Having said that, while the European Court of Human Rights has emphasised the link between the right to silence and access to pre-trial legal advice it has not, to date, insisted that solicitors be present throughout interrogation

\section{Legal professional privilege}

Whether a suspect accesses legal advice only in advance of police interview, or has his solicitor present throughout, a difficulty which may later arise if he seeks to avoid the drawing of inferences from silence during such interview relates to legal professional privilege. This issue arose in the context of s 34 in England and Wales. Legal professional privilege is an important procedural protection afforded to accused persons in the criminal justice system. Its rationale is that a client should feel free to explain everything to his/her legal adviser without fear that such information will be used against him/her or will go beyond his/her confidential relationship with his/her legal adviser. If an accused person were to claim that his/her solicitor, to whom s/he explained everything, advised a 'no comment' interview and that was why the accused did not consider it reasonable to mention any particular fact at that time, it might well be necessary for the solicitor, to avoid the drawing of inferences, to clarify the reasons for his/her advice, and thus privilege would be waived. Once privilege is 
waived, the prosecution are free to ask questions on all of the communications between the suspect and his/her solicitor.

The effect of s 34 on legal professional privilege was alluded to in $R v$ Beckles where Lord Woolf C.J. noted the following:

'Where the reason put forward by a defendant for not answering questions is that he is acting on legal advice, the position is singularly delicate. On the one hand the Courts have not unreasonably wanted to avoid defendants driving a coach and horses through section 34 and by so doing defeating the statutory objective. Such an explanation is very easy for a defendant to advance and difficult to investigate because of legal professional privilege. On the other hand, it is of the greatest importance that defendants should be able to be advised by their lawyer without their having to reveal the terms of that advice if they act in accordance with that advice' (at 2843).

If pressure is placed on a suspect who wishes to avoid the drawing of adverse inferences to waive his/her legal professional privilege so as to explain to the jury the grounds on which silence was advised and facts were therefore not mentioned, there is a threat to the continued existence of a meaningful legal professional privilege. This, in turn, threatens the quality of legal advice which can be provided to suspects detained for questioning by the police.

\section{Conclusion}

The complexity of explaining inference-drawing provisions to a jury creates difficulties in itself. It seems an onerous and confusing task for a jury to determine, ex 
post facto, whether a particular suspect genuinely relied on the advice which s/he received from his/her solicitor and whether it was reasonable in the circumstances as they existed at that time for him/her to do so. Furthermore, the very fact of inviting the jury to choose to draw inferences from silence if it sees fit carries the danger of potentially placing an unwarranted level of emphasis on the failure of the suspect to mention a particular fact in the pre-trial process, in the eyes of the jury. The primary question for the jury, of course, is whether or not the accused is guilty. Complicated judicial directions on the inferences which may or may not be drawn may unduly distract from this central question.

A related point centres on the value of evidence of silence. Clearly, the aim of inference-drawing provisions is to encourage a suspect in the pre-trial process to provide information to the police, but the evidential value of inferences drawn from failure to mention a specific fact relied on at trial must be questioned. There could be many reasons not consistent with guilt for this failure, e.g. embarrassment, distrust of the police, and misunderstanding. Furthermore, s 89A in NSW does not include any requirement of police disclosure of existing evidence in advance of questioning where silence leads to possible inference. The interference with silence might be more palatable, and indeed stronger in evidentiary terms, if it did. It can be suggested, in any event, that a strong case against a particular accused does not need to rely on inferences from silence and a weak case should not result in conviction based only, or even primarily, on such inference alone. Irish legislative provisions specifically make this point, requiring that a conviction should not be based solely or mainly on an inference, but the NSW legislation only prohibits reliance on inference as the sole basis for conviction (s 89A(5)(b)). This element of s 89A (and indeed s 146A(3) of 
the Criminal Procedure Amendment (Mandatory Pre-Trial Defence Disclosure) Act 2013) should certainly be reviewed at an early opportunity.

The absence of duty solicitor schemes is another issue which ought to be reviewed. The NSW legislature's efforts to side-step the necessity of creating a duty solicitor, or similar, scheme by providing that inferences shall not be drawn against a suspect who has not been cautioned in the presence of an Australian legal practitioner and had an opportunity to consult in private with such a practitioner about the nature and effect of such a caution are clumsy and half-hearted. In an alleged attempt to apply the inference-drawing provision to offences at the "higher end of criminal activity", the legislature has deemed s 89A almost inapplicable from the outset by allowing that no inferences can be drawn against a suspect who did not have access to legal advice. As it becomes clear that inferences are easily avoided by not retaining a lawyer, s 89A may be rendered toothless in a large number of cases.

Of course, that, in this author's view would be a good thing! Interference with the right to silence achieves little in reality, creates complications and confusion, and opens the gate to further intrusions on well-established rights in the future. If the development of the Irish criminal process shows nothing else, it shows that legislation enacted to address specific perceived needs at a given time easily finds itself in operation in broader contexts, gaining legitimacy through enactment, usage and the passage of time. Interferences with the right to silence in Ireland have suffered from 'function creep', to the detriment of the protection of that right. Bit by bit, little by little, incursions on the right to silence have altered and expanded. The acceptance of s 89A in NSW along with inference-drawing provisions relating to defective defence disclosure, may lead to the same type of normalisation and expansion of interference 
with the long-established right to silence and once the Rubicon has been crossed, the other states of Australia may well follow suit.

\section{$\underline{\text { List of Cases }}$}

$\underline{\text { Australia }}$

Hammond $v$ The Commonwealth [1982] HCA 42

$R v$ Seller and McCarthy [2012] NSWSC 934

\section{$\underline{\text { Canada }}$}

Thomson Newspapers Ltd. $v$ Canada (Director of Investigation and Research, Restrictive Trade Practices Commission) [1990] 1 SCR 425

\section{England and Wales/United Kingdom}

Cadder v Her Majesty's Advocate [2010] UKSC 43 (October 26, 2010)

$R v$ Beckles [2005] 1 W.L.R. 2829

$R v$ Betts and Hall [2001] 2 Cr. App. R. 257

R. v Director of the Serious Fraud Office, ex p. Smith [1993] AC 1

$R v$ Hoare and Pierce [2005] 1 W.L.R. 1804

$R v$ Howell [2005] 1 Cr. App. R. 1

$R v$ Essa [2009] EWCA Crim 43

European Court of Human Rights

Beckles v U.K. (2002) 36 EHRR 162

Condron v U.K. (2001) 31 EHRR 1 
Funke v France (1993) 16 EHRR 297

Heaney and McGuinness v Ireland (2001) 33 EHRR 334

Murray v United Kingdom (1996) 22 EHRR 29

Salduz v Turkey (2008) 49 EHRR 421

Saunders v United Kingdom (1996) 23 EHRR 313

$\underline{\text { Ireland }}$

Barry v Waldron Unreported High Court 23 May 1996

Dunnes Stores v Ryan [2002] 2 IR 60

Heaney and McGuinness v Ireland [1996] 1 IR 580

Lavery v Member-in-Charge, Carrickmacross Garda Station [1999] 2 IR 390

O'Brien v D.P.P. [2005] IESC 29

People (D.P.P.) v Healy [1990] 2 IR 73

Re National Irish Bank (under investigation) (No.1) [1999] 3 I.R. 145

\section{$\underline{\text { United States }}$}

Miranda v Arizona 384 U.S. 436 (1966)

Murphy $v$ Waterfront Commission of New York Harbor 378 US 52 (1964)

\section{Constitution}

Bunreacht na hEireann (Constitution of Ireland) 1937

\section{$\underline{\text { Legislation }}$}

$\underline{\text { Australia }}$

Evidence Amendment (Evidence of Silence) Bill 2012 
Evidence Amendment (Evidence of Silence) Bill 2013

Evidence Amendment (Evidence of Silence) Act 2013

Criminal Procedure Amendment (Pre-Trial Defence Disclosure) Act 2013

England and Wales

Criminal Justice and Public Order Act 1994

Criminal Procedure and Investigations Act 1996

$\underline{\text { International }}$

European Convention on Human Rights and Fundamental Freedoms 1950

International Covenant on Civil and Political Rights 1966

Statute of the International Tribunal for the Former Yugoslavia 1993

Statute of the International Tribunal for Rwanda 1994

Rome Statute of the International Criminal Court 1998

$\underline{\text { Ireland }}$

Constitution (Amendment No.17) Act 1931

Offences Against the State Act 1939

Criminal Justice Act 1984

Criminal Justice (Drug Trafficking) Act 1996

Criminal Law Act 1997

Offences Against the State (Amendment) Act 1998

Criminal Justice Act 2006

Criminal Justice Act 2007

Criminal Justice (Amendment) Act 2009 
Criminal Justice Act 2011

New Zealand

New Zealand Bill of Rights Act 1990

Evidence Act 2006

Search and Surveillance Act 2012

$\underline{\text { Northern Ireland }}$

Criminal Evidence (Northern Ireland) Order 1988

\section{$\underline{\text { Singapore }}$}

Criminal Procedure Code (Spore)

Criminal Procedure (Amendment) Act 1976 (Spore)

\section{$\underline{\text { References }}$}

Committee to Recommend Certain Safeguards for Persons in Custody and for Members of an Garda Sìochána 1978 Report Stationery Office Dublin

Criminal Law Revision Committee $197211^{\text {th }}$ Report HMSO London Cmnd. 4991

Criminal Legal Aid Review Committee 2002 Final Report Stationery Office Dublin 
Cross, ARN (1970-71) "The Right to Silence and the Presumption of Innocence Sacred Cows or Safeguards of Liberty?" Journal of the Society of Public Teachers of Law vol 11 p 66

Crown Court Bench Book: Directing the Jury 2010 <http://www.judiciary.gov.uk/Resources/JCO/Documents/Training/benchbook_crimi nal_2010.pdf> accessed 22 February 2013

Daly, YM 2007 “Solicitor and Silence: Lessons Learned from England and Wales" Irish Criminal Law Journal vol 17 no 2 p 2

Daly, YM 2009 "Is Silence Golden? The Legislative and Judicial Treatment of PreTrial Silence in Ireland” Dublin University Law Journal vol 31 p 35

Dennis, I 1995 “Instrumental Protection, Human Right or Functional Necessity? Reassessing the Privilege against Self-Incrimination" Cambridge Law Journal vol 54 p 342

Easton, S 1998 The Case for the Right to Silence Amesbury Series in Philosophy

Gans, J 2012 submission to the Department of the Attorney General and Justice on the Evidence Amendment (Evidence of Silence) Bill 2012 (copy with author)

Heffernan L. 2011 “The Right to Legal Advice, Reasonable Access and the Remedy of Excluding Evidence" Criminal Law and Procedure Review vol 1 p 123 
Herman, L 1992 “The Unexplored Relationship between the Privilege Against Compulsory Self-Incrimination and the Involuntary Confession Rule" (Part I) Ohio State Law Journal vol 53 p 101, (Part II) p 497

Hillyard, P 1993 Suspect Community: People's Experience of the Prevention of Terrorism Acts in Britain Pluto Press

Jackson, J 2009 "Re-conceptualizing the right to silence as an effective fair trial standard" International and Comparative Law Quarterly vol 58 p 835

Langbein, JH 1994"The Historical Origins of the Privilege Against Self-Incrimination at Common Law” Michigan Law Review Vol 92 p 1047

Leo, RA 1996 “Miranda’s Revenge: Police Interrogation as a Confidence Game” Law and Society Review vol 30 no 2 p 259

Maguire, M 1994 “The Wrong Message at the Wrong Time? The Present State of Investigative Practice" in Morgan, D and Stephenson, GM (eds) Suspicion and Silence - The Right to Silence in Criminal Investigations Blackstone Press Ltd London

McConville, M, Sanders, A and Leng, R 1991 The Case for the Prosecution Routledge London 
McGrath, D Evidence 2005 Thomson Round Hall Dublin

NSW Law Reform Commission 2000 Report 95 The Right to Silence

NSW Bar Association 2012 submission to the Department of the Attorney General and Justice on the Evidence Amendment (Evidence of Silence) Bill 2012 <http://www.nswbar.asn.au/circulars/2012/sep/r2s.pdf $>$ accessed 22 February 2013

O’Connor, PA and Cooney, TA 1980 “Criminal Due Process, the Pre-Trial Stage and Self-Incrimination” Irish Jurist vol 15 p 219.

$\begin{array}{llllll}\text { O'Farrell, } & \text { B, } & \text { Press } & \text { Release } & \text { August } & 14\end{array}$ $<$ http://www.premier.nsw.gov.au/sites/default/files/CRIME\%20CRACKDOWN\%20 RIGHT\%20TO\%20SILENCE\%20LAW\%20TOUGHENED.pdf> $>\quad$ accessed 22 February 2013

Packer, H.L. 1968 The Limits of the Criminal Sanction Stanford University Press Stanford

Royal Commission on Criminal Justice 1993 Report HMSO London Cmnd. 2263

Smith, G, Evidence Amendment (Evidence of Silence) Bill 2013 and Criminal Procedure Amendment (Pre-Trial Defence Disclosure) Bill 2013 Second Reading 13 March 2013 
<http://www.parliament.nsw.gov.au/prod/parlment/nswbills.nsf/0/8d7f969c28b98e79 ca257b2d00137b1d/\$FILE/2R\%20Evidence\%20Amendment.pdf> accessed May 27 2013

Tormey Committee 1977 First Interim Report Stationery Office Dublin

Walsh, D 1989 "The Impact of Anti-Subversive Laws on Police Powers and Practice in Ireland: The Silent Erosion of Individual Freedom" Temple Law Review vol $62 \mathrm{p}$ 1099

White, J.P.M. 2000 "The Confessional State - Police Interrogation in the Irish Republic" Part I Irish Criminal Law Journal vol 10 no 1 p 17

Wigmore, JH Evidence 1940 Third Edition Vol. VIII (McNaughton rev. 1961)

Working Group on the Right to Silence 1989 Report Home Office HMSO London Zuckerman, AAS 1989 The Principles of Criminal Evidence Clarendon Press Oxford Zuckerman, AAS 1994 "Bias and Suggestibility: Is there an alternative to the Right to Silence" in Morgan, D and Stephenson, GM (eds) Suspicion and Silence - The Right to Silence in Criminal Investigations Blackstone Press Ltd London 